\author{
JAN NIEWĘGLOWSKI* \\ Warsaw, Poland \\ ORCID ID oooo-0oo1-9673-4989
}

\title{
WORK FROM THE PERSPECTIVE OF CARDINAL STEFAN WYSZY ŃSKI. PEDAGOGICAL IMPLICATIONS
}

\begin{abstract}
The organization of human life in accordance with the many possibilities of labour should be matched by a suitable system of instruction and education, aimed first of all at developing mature human beings, but also aimed at preparing people specifically for assuming to good advantage an appropriate place in the vast and socially differentiated world of work.
\end{abstract}

(John Paul II, Laborem exercens, 18)

\begin{abstract}
In his abundant teaching, Cardinal Stefan Wyszyński devoted a lot of attention to the question of work, its significance in human life and the role it plays in the process of education. The Primate claimed that education for work cannot be brought down to developing manual competences necessary to perform a given profession, but that it should be a process aimed at discovering the meaning of work itself. In order to understand that meaning properly, Cardinal Wyszyński analysed the text of the Book of Genesis, which tells about the Creator and His "work" in terms of creating the world. Man is a "child of God", that is, a thinking being endowed with an inquiring mind and capable of grasping the transcendent dimension of his existence. The work performed by man cannot be senseless duplication of the Creator's deeds, but rather independent human thinking and action. Education for work must be complemented by virtue, for it is virtue that enriches man and allows him to become the performer and creator of work, and not the other way around.
\end{abstract}

Keywords: work, economy, sense of work, education for work, homo laborans.

\section{Introduction}

Economics is one of the most important aspects of modern life. In Poland, before 1989 the economic system was based on a different model. After numerous political changes in the 1990s, Polish society found itself in a new social reality, in which also work gained a different dimension. Today, unfortunately, there is a growing

* Ks. dr hab. Jan Niewęgłowski, prof. UKSW, absolwent Universitá Pontificia Salesiana, prof. nadzwyczajny w Uniwersytecie Kardynała Stefana Wyszyńskiego w Warszawie, e-mail: j.nieweglowski@uksw.edu.pl. 
tendency to view any human activity from the perspective of profit and loss. This phenomenon specifically affects the sphere of work, which is frequently perceived as a way to accumulate goods and multiply capital. Consequently, a person performing work becomes a machine or a tool, which is more or less efficient. It appears that the modern worker is forced to care more about productivity than about his own spiritual development. However, when deprived of that perspective, he is no longer happy and work does not bring him full satisfaction (Wiatrowski 2010, p. 64).

More and more often people want to "have more rather than be more". The ability of young people to understand both the value and the risks associated with work depends largely on their education. In search of answers to the above issues, it is worth referring to the thoughts of Cardinal Stefan Wyszyński. It seems that his reflection, thought and teaching on the meaning of work and education in human life, proclaimed many years ago, are still valid ${ }^{1}$.

\section{God's “work” in Genesis}

In his reflection on the meaning of work, Stefan Wyszyński referred to the Bible, and specifically to the Book of Genesis. The Primate of Poland saw the work of man in God's work. In this understanding, human work became "a continuation of God's creative work" (Wyszyński 1991, p. 56). Basing on the historical-critical method, Wyszyński drew conclusions through analogy. Both God's "work" and human work were, according to him, inextricably linked. Therefore, in his seminal book Duch pracyludzkiej (The Spirit of Human Work), the Primate argued that in human work we should perceive not only the outer and material dimension, but also the spiritual and supernatural one.

Any activity undertaken by man out of love for God can also become his prayer. Work as such does not replace prayer, however, it can become prayer when leading man towards a meeting with the Creator. Actions undertaken and carried out for the sake of God's love engage man, moreover, in the work of redeeming this world, since work has an expiatory nature for sins. However, work can only fulfil such a role, providing it is performed with the right intention. When deprived of such a good intention, work loses its spiritual dimension and, consequently, man is turned into a slave of the matter (ibid., p. 71).

The first passages of Genesis have been dealt with by manifold sciences trying to explain the meaning as well as the essence of the world's creation. Among those sciences, theology comes to the fore in this respect. Rather than explaining biological processes, it highlights the fact that man is a unique creature among a wide range of other creatures. This uniqueness lies in the fact that man has been invited to cooperate with God in improving the existing world. This truth

1 This is confirmed by Pope Francis, declaring Cardinal Stefan Wyszyński as Blessed of the Catholic Church. 
is emphasized by the description of the world's creation (Genesis 1-2). However, this description is not a scientific interpretation of the creation of the world, but a religious reflection on man and his relationship with God. Cardinal Wyszyński, referring to the first two chapters of the Book of Genesis, emphasized that the entire universe reflects the greatness and splendour of the Creator. Man, in turn, apart from being the crowning achievement of the work of creation, was created in the image and likeness of God. In the end, the Creator bestows a blessing on man. According to Wyszyński, that act is a confirmation of the truth that God values life and wants it to develop continuingly. The command "Be fruitful, and multiply, and replenish the earth, and subdue it" (Genesis 1,28 ) is read by Wyszyński as an order to work.

Adopting, as the Primate postulated, the concept of man as God's creation, leads to consequences which he referred to as the process of "humanizing man" (Wyszyński 2001b, p. 28). Man, being a child of God, has a duty to work on himself in order to become like his Father. "It is the work of humanizing humans. Forgive me for the juxtaposition of words, but I would like to state it emphatically. The point is that man cannot be a beast, but a human being; that his fangs must be broken, and his style softened; that modern man should get rid of hostility, animosity, anger [...]; that he should abandon the disgraceful manners of shaking his fist right and left at all people. The point is that the light of God's Face should be reflected in each of us. This is the essence of the work of the Church on humanizing man" (ibid.).

When pointing to the exceptional distinction of man as the crowning achievement of the entire material universe, the Primate writes: This thought is beautifully expressed by Michelangelo in the "creation of Adam". God touches Adam with the tip of the fingers of His creative hand as he awakens him to life. All around is solitude: there are no witnesses in God's studio - only God and man! Solitude is meaningful: it tells us that man in his initial being is dependent on God. [...] Whatever Man possesses was bestowed on him by God. It is the work of God's fingers, and the most important gifts that decide on our human character, i.e., the immortal soul, reason and will, we received from God (Wyszyński 1993a, p. 48). Although man occupies the leading position among other creatures, according to Wyszyński, he is not a fully completed creature. In his teaching, the Cardinal often mentioned the issue of the human inherent ability and possibility to develop himself. In his opinion, the education process, should consist in continuous discovery of one's own imperfections and in constant learning. "The great misfortune of the modern world is that people think miserably about themselves because they later add to such thinking a miserable lifestyle and they can easily justify themselves. They often say that man is after all only a human being, so he can have a miserable life... If only we changed the way in which we perceive a person and said rather: Man is a human being after all! Let his deeds, then, match the measure of humanity" (Wyszyński 2001a, p. 21). 
In the statement "Be fruitful, and multiply, and replenish the earth, and subdue it: and have dominion over the fish of the sea, and over the fowl of the air, and over every living thing that moveth upon the earth" (Genesis 1.28), Wyszyński sees the task of ruling over creation and working on oneself, but he also points to the subject expressing this command: "God said unto them" (Genesis 1:28). This way, the Creator becomes the educator of man, whom he encourages to act and work. Moreover, the God-Educator wishes to share knowledge and power with man. The latter is not an absolute power as it implies responsibility towards all nature. This responsibility is manifested in respect for the earth and its natural resources. GodEducator opens up for man the opportunity to participate in His action. Although man does not have the power to create, he can nevertheless be co-responsible for the entire created universe. Moreover, as Primate Wyszyński emphasizes, the GodEducator has not left the disciple to his own means, but looks after him, cares for him and supports him in managing the entire creation (Wyszyński 1993c, p. 268).

Cardinal Wyszyński also highlights another aspect. In the biblical paradise, man apart from work, had the opportunity to stay close to God, to observe and to learn how to fulfil God's command to take care of the earth. The Creator does not address this command to all creatures, but to man as His most perfect creation. Because it is only man who can hear this command, understand it and put it into practice. "God planted man on the earth and defined his duties on the earth. [...] The earth is for man, not man for the earth. [...] Man and the dignity of human nature, issuing from the divine origin of man take priority on the earth. [...] This is the direction of human development: in the temporal order as the development of the personality through culture, and in the eternal order in the deification of the personality. The goal of this development is to reach the Creator" (Wyszyński 2001a, p. 43).

The God-Educator wants the disciple-man to be co-responsible for creation. The Creator shares with man His knowledge, power, and responsibility for the world. The biblical text is the first verbalized act of education. It should be noted at this point that the Primate, although referring to the biblical perspective, did not regard the religious aspect as having a priority in the wide area of human "praxis". The very expression "subdue the earth" rather than being interpreted as assigning man with a specific task or a targeted activity should be interpreted as an encouragement to get to know oneself and the surrounding reality. The process of self-cognition will allow man to acknowledge his extraordinary dignity and the greatness of his humanity, and it is that very purpose that education should serve (Furmanek, 2010, p. 112). "A good attitude towards oneself should provide basis of every healthy education of man, that is, of making him capable of fulfilling all his life tasks. It is necessary to understand who I am, what is my nature and what I strive for" (Wyszyński 1993d, p. 109). 


\section{Education through work}

Cardinal Stefan Wyszyński pointed out two elements necessary to build a proper relationship between work and education. The first one consists of the task of shaping intergenerational relations. The second relies on acknowledging the transcendent and spiritual dimension of work. Education for the Primate meant a social activity. Its principal goal was to prepare young people to a life in society and for society (Niemiec 2010, p. 72). "Just as in the social organism there is a relationship between individual states and professions, so strong that one state and profession cannot fully develop without the cooperation and help of other members of the social body" (Wyszyński 2001b, p. 484), in educational activities, one should take into account the factors conditioning the development of an individual person, the obligation to work on oneself and on the development of the whole society. In this context, Wyszyński wrote: "Man is a social being, not only because he needs society for his full development, but also because he contributes to society, communicates something, influences it, weaker or stronger, bad or good, depending on manifold circumstances" (ibid., p. 491).

Cardinal Wyszyński linked the performance of work and education for work with the concept of "moral order". The Primate presented his views on this subject particularly in the above-mentioned book Duch pracy ludzkiej as well as and in the article "Duszpasterz w budowaniu ustroju korporacyjnego" (The Priest in Building a Corporate System). Wyszyński provided there a description of human work and the features that should characterise it. "Work [...] should contribute to developing certain skills, virtues, and values of inner life. In other words, it is about the special asceticism of our daily work! Thus, inner work has its rights with regard to outer work which cannot be overlooked. The first of them is that inner life provides a basis for outer life" (Wyszyński 1991, p. 63). He further argued that there are certain virtues that could be referred to as "work virtues". These include patience, long-term thinking, perseverance, and its related consistency, as well as meekness and conscientiousness (ibid., pp. 72-94).

Primate Wyszyński derived the concept of "moral order" from the teachings of Pius XI. The Pope, while rejecting capitalism and scientific socialism, proposed a different path, namely, that of a corporate system uniting both workers and employers. Cardinal Wyszyński regarded that system as the best form of social and economic life because, as he said it "lies at the opposite extreme of both individualism and collectivism" (Wyszyński 2001c, p. 53). In its assumptions, corporatism emphasized the individual and social value of a human being. The idea of corporatism is complemented by the possibility of human development, which happens through love. That love translates into toil, effort, and readiness to sacrifice oneself for the benefit of another person. In educational activities one should look for such methods and means that would allow to understand the performed work primarily as service, and especially, service for the poor. 
For the Primate, the "moral order" rests on the three main theological virtues, namely, faith, hope and love. And the very concept of virtue was for Wyszyński associated with the category of a person's maturity, which he did not identify with age. According to Cardinal Wyszyński, even a young person who can make decisions in an independent and responsible manner can be regarded as a mature person. Such a mature person is one who is constantly looking for ways and means for comprehensive development (Baraniak 2010, p. 141). In one of the homilies, Wyszyński stated: "The state cannot define its educational ideal only as the citizen and his civic virtues, but as the whole person. It is because, the state, in order to achieve full happiness, needs all human virtues, not only the civic ones. And this work cannot be realized by the state alone, without the help of the family, the Church, nation, society and profession. [...] The Church develops such virtues in the citizen, which the state would by no means be able to develop on its own" (Wyszyński 1993b, p. 141).

Another component of the "moral order", according to the Primate, was the question of people's ability to cooperate with others. Wyszyński understood it as toil, effort and even suffering that a person can experience when undertaking work for the benefit of the nation, his own family, or the local community. "All these virtues", writes the Primate, "especially the so-called social virtues have an undeniable impact on social relations. Calling the faithful to practice these virtues, namely, to justice, love, honesty, goodness, generosity, forbearance, or to willingly forgive offenses, is an enormous help as it allows to cement society in a corporate spirit. These virtues put an end to the class struggle, hatred, greed, exploitation, usury and selfishness" (Wyszyński 2001b, p. 486). A joint work contributes to building a community. People have a sense of unity, integrate with one another and turn into a community of various services. The effort undertaken in a community leads to creating interpersonal bonds. "Our work", as the Primate writes, "will accentuate our love for our neighbour and our pliability and obedience, humility, selflessness, the spirit of recollection, conscientiousness and prudence" (ibid.). In this sense, work takes on a dialogical character, it eliminates anonymity isolating a person from the community and it allows to build the bonds of group solidarity (Kopiec 2012, p. 140).

Searching for the common denominator of work and education, Cardinal Wyszyński pointed to religion. It is only in the religious perspective that the original meaning of the notion of virtue issuing from this relationship is truly revealed. Virtue cannot be brought down to a single human ability since virtue is the very relationship: religion - education - work. Such hierarchization makes this relationship perfect, wise, and properly ordered. The Primate claimed that a man, thinking harmoniously about religion, work, and education, tends towards virtue. This virtue is manifested in practice by common service and cooperation. A relationship based on the virtue of order and harmony allows man to find an antidote to the dictates of economy in human life. The presence of religion in the 
work-education relationship contributes to the fact that none of the elements is dominant and that they do not exclude one another but become equal. When referring them to the sphere of interpersonal relations, the Primate recurrently advocates actions that involve compromise, dialogue, and respect for every human being. In his sermon "Państwo bojące się Boga" (The pious state), he said: "What the Church teaches the citizens in the first place is truth. The whole mutual relation of one citizen toward another and toward the state must be based on truth. [...] Who does not realize how important this teaching is for public life, how it guards against illusions and disappointments, how it makes life easier and how it improves it! Let us teach truth to citizens, and we will build the power of the state: we will fill state coffers with a penny of conscientious payers, we will protect ourselves from illusions, we will eradicate lies that ruin public life, unscrupulousness and blasphemy" (Wyszyński 1993b, p. 141). Similarly, in terms of education for work, the Primate claimed that this process cannot be aimed solely at preparing young people to commencing work and practicing a profession. Such skills are developed through vocational training. The aim of education for work, on the other hand, should be to teach young people to think about work in an independent and responsible way.

\section{Conclusion}

When considering the relationship between work, education and religion, Primate Wyszyński saw absolutely no rivalry among those values. None of them takes priority here. The virtue of faith only sheds a specific light on the work undertaken by people and makes it easier for them to see the purpose of their actions. Cardinal Wyszyński often emphasized that his point of view was one of the proposals that could be used in the process of educating young people for work. However, he appealed for acknowledging the importance of the existence and presence of religion in a person's life. In his teaching, he also addressed non-believers, suggesting that they should likewise ask themselves about the fundamental goal of education for work. According to the Primate, education for work cannot be limited only to the path of manual preparation. Understanding work and educating for work is a process throughout which a person not only learns to work (poiesis), but also learns to think about work (praxis). In Wyszyński's opinion, including religion in education will make it easier for the teacher and pupil to accept and understand the teleological nature of work and education. The perspective of transcendence allows work to free itself from the bondage of immanentism and gives it a higher meaning and significance. And the highest sense of work for man is his salvation. 


\section{References}

Baraniak, B. (2010). Antropocentryczna wizja pracy kard. Stefana Wyszyńskiego. In: O społeczeństwie, wychowaniu i pracy w myśli kardynała Stefana Wyszyńskiego, ed. L. Marszałek, A. Solak, 141-150. Warszawa: UKSW.

Furmanek, W. (2010). Cechy pracującego człowieka obiektem badań współczesnej pedagogiki pracy. Inspiracje kard. Stefana Wyszyńskiego. In: O społeczeństwie, wychowaniu i pracy w myśli kardynała Stefana Wyszyńskiego, ed. L. Marszałek, A. Solak, 103-115. Warszawa: UKSW.

Jan Paweł II (200o). Laborem exercens. In: J. Życiński (ed.). Encykliki Ojca Świętego Jan Pawła II. Kraków: Znak.

Kopiec, H., (2012). Kontrowersje wokół pracy jako wartości wychowawczej. in: Człowiek w pedagogice pracy, ed. B. Baraniak, 135-159. Warszawa: Difin.

Niemiec, J. (2010). Tytani miłości wiary i miłości Ojczyzny. W: O społeczeństwie, wychowaniu i pracy w myśli kardynała Stefana Wyszyńskiego, ed. L. Marszałek, A. Solak, 69-77. Warszawa: UKSW.

Wiatrowski, Z. (2010). Powinnościowy charakter pracy człowieka w wersji kard. Stefana Wyszyńskiego. In: O społeczeństwie, wychowaniu i pracy w myśli kardynała Stefana Wyszyńskiego, ed. L. Marszałek, A. Solak, 61-68. Warszawa: UKSW.

Wyszyński, S. (1991). Duch pracy ludzkiej. Myśli o wartości pracy. Warszawa: Wydawnictwo im. Stefana Kard. Wyszyńskiego Soli Deo.

Wyszyński, S. (1993a). Człowiek - istota nieznana. W: S. Wyszyński. Miłość i sprawiedliwość społeczna. Rozważania społeczne. Poznań: Pallottinum.

Wyszyński, S. (1993b). Państwo bojące się Boga. W: S. Wyszyński. Miłość i sprawiedliwość społeczna. Rozważania społeczne. Poznań: Pallottinum.

Wyszyński, S. (2001b). Duszpasterz w budowaniu ustroju korporacyjnego. W: S. Wyszyński, Katolicka nauka społeczna. Wybór artykułów z „Ateneum Kapłańskiego” z lat 1929-1946. Włocławek: Wydawnictwo WSD.

Wyszyński, S. (1993c). Przyrodzony ustrój społeczny. In: S. Wyszyński. Miłość i sprawiedliwość społeczna. Rozważania społeczne. Poznań: Pallottinum.

Wyszyński, S. (1993d). Wychowanie katolickie. In: S. Wyszyński. Miłość i sprawiedliwość społeczna. Rozważania społeczne. Poznań: Pallottinum.

Wyszyński, S. (2001a). Prymat człowieka na globie. In: S. Wyszyński. Idzie nowych ludzi plemię... Wybór przemówień i rozważań. Poznań: Pallottinum.

Wyszyński, S. (2001b). Środki Bożego awansu człowieczeństwa i chrześcijańskiego humanizmu. In: S. Wyszyński. Idzie nowych ludzi plemię... Wybór przemówień i rozważań. Poznań: Pallotinum.

Wyszyński, S. (2001c). Początki nauczania społecznego 1934-1939. Warszawa: Instytut Wydawniczy PAX.

Wyszyński, S. (2001d). Znak zwycięstwa $w$ walce o poszanowanie i ratunek człowieka. In: S. Wyszyński, Idzie nowych ludzi plemię... Wybór przemówień i rozważań. Poznań: Pallotinum. 


\title{
PRACA W UJECIU KARDYNAŁA STEFANA WYSZYŃSKIEGO. IMPLIKACJE PEDAGOGICZNE
}

\begin{abstract}
Abstrakt: Kardynał Stefan Wyszyński w swoim bogatym nauczaniu wiele uwagi poświęcił kwestii pracy, jej znaczeniu w życiu człowieka oraz roli, jaką pełni w procesie wychowania. Prymas uważał, że wychowanie do pracy nie sprowadza się do rozwijania kompetencji manualnych niezbędnych do wykonywania danego zawodu, ale powinno być procesem mającym na celu odkrycie sensu samej pracy. Aby właściwie zrozumieć to znaczenie, kard. Wyszyński przeanalizował tekst Księgi Rodzaju, która mówi o Stwórcy i Jego „dziele” w kontekście stworzenia świata. Człowiek jest „dzieckiem Bożym”, czyli istotą myślącą, obdarzony jest dociekliwym umysłem i zdolny do uchwycenia transcendentnego wymiaru swojej egzystencji. Praca człowieka nie może być bezsensownym powielaniem czynów Stwórcy, ale raczej niezależnym ludzkim myśleniem i działaniem. Wychowanie do pracy musi być uzupełnione cnotą, bo to cnota wzbogaca człowieka i pozwala mu stać się wykonawcą i twórcą dzieła, a nie odwrotnie.
\end{abstract}

Słowa kluczowe: praca, ekonomia, poczucie pracy, wychowanie do pracy, homo laborans. 
